\title{
Future Forest Cover Change Scenarios with Implications for Landslide Risk: An Example from Buzau Subcarpathians, Romania
}

\author{
Žiga Malek ${ }^{1,2} \cdot$ Luc Boerboom $^{3} \cdot$ Thomas Glade $^{2}$
}

Received: 3 November 2014/ Accepted: 20 June 2015/Published online: 30 June 2015

(C) Springer Science+Business Media New York 2015

\begin{abstract}
This study focuses on future forest cover change in Buzau Subcarpathians, a landslide prone region in Romania. Past and current trends suggest that the area might expect a future increase in deforestation. We developed spatially explicit scenarios until 2040 to analyze the spatial pattern of future forest cover change and potential changes to landslide risk. First, we generated transition probability maps using the weights of evidence method, followed by a cellular automata allocation model. We performed expert interviews, to develop two future forest management scenarios. The Alternative scenario (ALT) was defined by $67 \%$ more deforestation than the Business as Usual scenario (BAU). We integrated the simulated scenarios with a landslide susceptibility map. In both scenarios, most of deforestation was projected in areas where landslides are less likely to occur. Still, 483 (ALT) and 276 (BAU) ha of deforestation were projected on areas with a high-landslide occurrence likelihood. Thus, deforestation could lead to a local-scale increase in landslide risk, in particular near or adjacent to forestry roads. The parallel process of near $10 \%$ forest expansion until 2040 was
\end{abstract}

Žiga Malek

malekz@iiasa.ac.at

Luc Boerboom

l.g.j.boerboom@utwente.nl

Thomas Glade

thomas.glade@univie.ac.at

1 International Institute for Applied Systems Analysis (IIASA), Schlossplatz 1, 2361 Laxenburg, Austria

2 Department of Geography and Regional Research, University of Vienna, Universitätsstraße 7, 1010 Vienna, Austria

3 Faculty of Geo-Information Science and Earth Observation (ITC), University of Twente, Hengelosestraat 99, 7514 AE Enschede, The Netherlands projected to occur mostly on areas with high-landslide susceptibility. On a regional scale, forest expansion could so result in improved slope stability. We modeled two additional scenarios with an implemented landslide risk policy, excluding high-risk zones. The reduction of deforestation on high-risk areas was achieved without a drastic decrease in the accessibility of the areas. Together with forest expansion, it could therefore be used as a risk reduction strategy.

Keywords Forest change - Land-cover change ·

Scenarios · Spatial simulation · Carpathians · Landslide risk

\section{Introduction}

Changes to the forest cover can result in a variety of negative environmental consequences. Deforestation, for example, can affect the vegetation composition and water balance and can increase erosion rates (Glade 2003; Ghimire et al. 2013). This leads to increased environmental risks, such as landslide occurrence, and can have strong impacts on the human wellbeing on a larger scale (Tasser et al. 2003; Körner et al. 2005; Papathoma-Köhle and Glade 2013). Reforestation due to grassland abandonment can also lead to negative consequences, among them habitat loss, lower biodiversity levels, and a more homogenous landscape (Olsson et al. 2000; Chemini and Rizzoli 2003). Studying how human-environment interactions can change the forest cover is therefore essential (Rounsevell et al. 2006).

Scenario development combined with land change models is an important tool for exploring future consequences of environmental changes (Verburg et al. 2004). Scenarios are images of possible, likely futures (Abildtrup et al. 2006). They encourage creativity and help generate 
visions and help us to plan for a desirable future (Deshler 1987). Moreover, by breaking the established pattern of planning, scenarios can help us to prepare for possible undesirable future developments (Wollenberg et al. 2000). They offer a possibility to analyze available response options, hence aiding decision makers (Shearer 2005; Kriegler et al. 2012). Scenarios of land change have thus been applied in numerous domains: impacts on flood risk (Barredo and Engelen 2010), soil erosion (Hessel et al. 2003), habitat availability (Falcucci et al. 2008), influence of protected areas (Soares-Filho et al. 2006), and effects on biodiversity levels (Giupponi et al. 2006).

In this study, we focus on future forest cover change scenarios of the Subcarpathians of Buzau County in Romania. Recent deforestation trends and a dense network of landslides in the area suggest a need for analyzing potential consequences of future forest management (Malek et al. 2014). Thus, we concentrated on possible future deforestation patterns, as a result of changes to the amount and pattern of forest harvesting. The area was selected due to its complex socio-economic trajectory since 1989, as well as growing pressures to increase forest harvesting.

The Carpathians are a major European mountain range and biodiversity hotspot, which host one of the largest continuous forest ecosystems in Europe. Forest expansion and deforestation are considered among the major environmental issues in the Carpathian region (Björnsen Gurung et al. 2009). Long-term forest expansion due to land abandonment in the Carpathian region is in line with the trends of other European mountain areas (Kozak et al. 2007b). The fall of communist regimes in Europe after 1989, however, leads to radical political and socio-economic changes in the region. The post 1989 era was characterized by the fall of large-scale collective agricultural associations, new landuse policies, and land ownership reforms resulting in numerous new land owners (Mathijs and Swinnen 1998; Lerman et al. 2004). Numerous authors identify land abandonment and reforestation as some of the most important land-cover changes in the region (Kuemmerle et al. 2008; Müller et al. 2009; Taff et al. 2009; Baumann et al. 2011; Griffiths et al. 2013). One particularly remarkable process, differing from other European mountain areas, is the increase in quantity and changes in the spatial pattern of deforestation as a consequence of both legal and illegal logging (Knorn et al. 2012; Griffiths et al. 2012, 2014). It is among the most significant land-cover change processes in Buzau Subcarpathians in terms of possible negative consequences (Malek et al. 2014).

The first objective of the study is to understand possible future changes to forest management in a transitional European mountainous region. More precisely, the objective is to generate future spatially explicit scenarios taking into account future changes to forest harvesting, instead of only extrapolating past trends. To achieve this, we combined geographic information systems (GIS) and land change modeling with expert interviews. Secondly, forest management in a mountainous and landslide prone area is closely linked to landslide risk management. Thus, the second objective was to investigate the relationship between future forest management and landslide risk. We overlaid the forest cover change scenarios with a landslide susceptibility map. Finally, our third objective was to analyze the effect of implementing a landslide risk reduction strategy for forest management. This was done, by excluding areas of high risk and evaluating the changes this had on the simulation outcomes.

\section{Study Area}

The study area (Fig. 1) lies in South East Romania in Buzau County (centroid $45^{\circ} 27^{\prime} 3^{\prime \prime} \mathrm{N}, 26^{\circ} 30^{\prime} 23^{\prime \prime} \mathrm{E}$ ). It covers $2421 \mathrm{~km}^{2}$ of the Subcarpathian hills between the higher Carpathian mountains and the Buzau plain. The Subcarpathians rise up to $1370 \mathrm{~m}$, with the mean elevation of the area being $429 \mathrm{~m}$. Geologically, the area consists mainly of Neogene molasse deposits. The geology of the area together with the mean slope of $11.5^{\circ}$ is a significant predisposing factor for landslide occurrence (Micu and Bălteanu 2013). The yearly precipitation in the area is between $630-700 \mathrm{~mm}$, with heavy spring and summer rainfall. In some parts of the Subcarpathians, landslides (Fig. 1a) cover more than twothirds of the total area (Muică and Turnock 2008). Forests dominate the landscape (Fig. 1b) covering $40.5 \%$ of the area $\left(981 \mathrm{~km}^{2}\right)$, followed by grasslands $(27.4 \%)$.

With a $40 \%$ share of the regional economy, agriculture is significant; however, it is declining (MADR 2012). Forest harvesting is a major economic activity, with wood mostly being exported (INSSE 2013). The area's population is around 160,000. Since the economic and political change of 1989, the area witnessed a striking economic decrease, high depopulation rates (11\% since 1990), and agricultural abandonment (INSSE 2013). Nevertheless, like in similar areas in the Romanian Carpathians, forest disturbances increased (Fig. 1c). This could be attributed to a number of reasons: (1) poor socio-economic conditions in the area following 1989; (2) Romanian land ownership reforms, where government owned land was allocated to private owners; and (3) difficulties in implementing forest policy (Malek et al. 2014). Before 1989, nearly $100 \%$ of the forests were government property, whereas in 2010, $34.7 \%$ of the forests were privately owned (INSSE 2013). Besides the increase in the number of owners, the ownership spatial pattern is characterized by numerous smaller plots, which increases the difficulty of forest management (Bălteanu and Popovici 2010). Increasing the amount of 
Fig. 1 Location of study area. Typical examples of a landslide activity, $\mathbf{b}$ forest-dominated landscape, and $\mathbf{c}$ deforestation

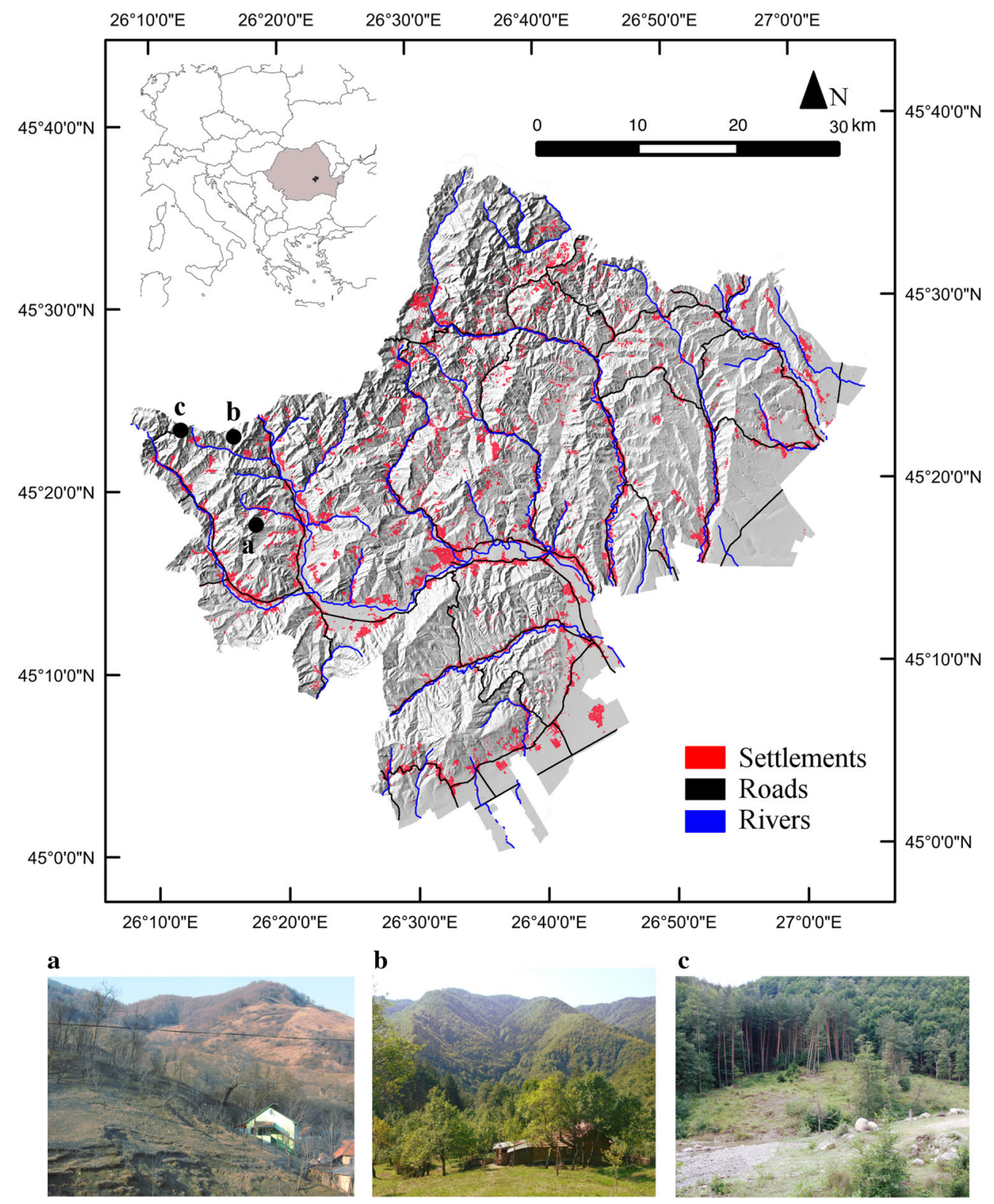

forest harvesting in the area could be a significant part of regional economic growth. It is, however, important to analyze the consequences of these activities in the area, as the increase in forest exploitation could result in a higher demand for new road and landslide risk mitigation infrastructure, as well as reforestation measures.

\section{Materials and Methods}

\section{Preparation of Spatial Factors of Forest Cover Change}

Forest cover maps for the years 1989, 2000, and 2010 were obtained through hybrid classification of LANDSAT images previously presented by Malek et al. (2014). The forest cover maps consisted of following classes, describing the changes to the forest cover between 1989 and 2010 (Fig. 2): persistent forest (stable forest), forest expansion (new forest), and deforestation (forest cover removed). The overall accuracies for the 1989, 2000, and 2010 forest cover maps are $85.7,87.3$, and $89.2 \%$, respectively. The post-classification accuracy assessment of the 1989-2010 forest cover change map (Table 1) revealed the accuracy of the change detection and estimated its uncertainty described as a $95 \%$ confidence interval (Olofsson et al. 2013; Malek et al. 2014).

We prepared the following spatial factors of forest cover change: slope and elevation derived from a $25 \mathrm{~m}$ resolution digital elevation model for Buzau County from IGAR 
Fig. 2 Forest cover map and with observed changes between 1989 and 2010
Table 1 Accuracy of 1989-2010 forest cover changes and the uncertainty defined as a $95 \%$ confidence interval $(\mathrm{CI})$ range

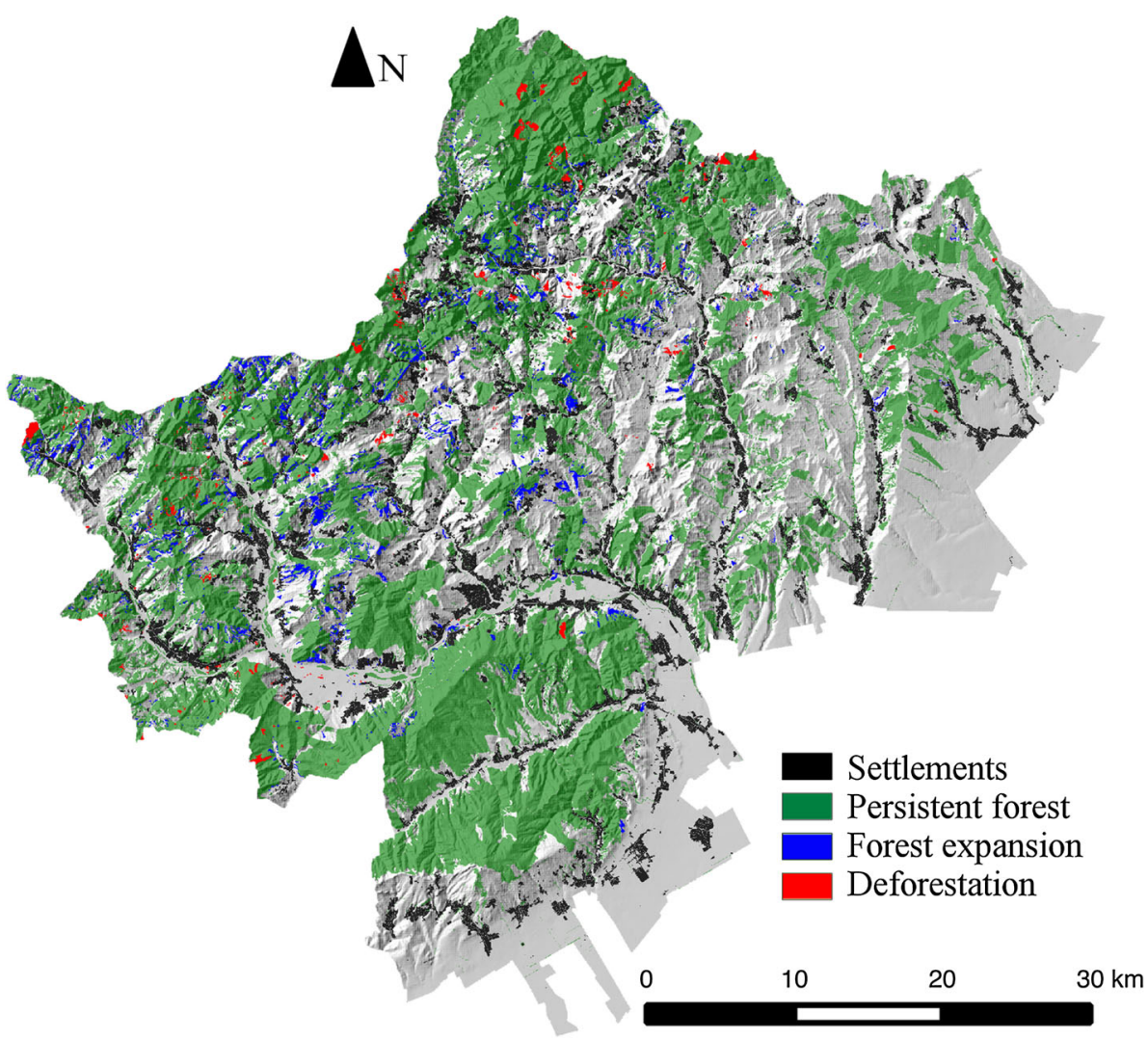

\begin{tabular}{lllc}
\hline Forest cover class & User's accuracy $(\%)$ & Producer's accuracy $(\%)$ & $95 \%$ CI $(\%)$ \\
\hline Persistent forest & 96.0 & 92.3 & 4.3 \\
Forest expansion & 84.0 & 85.7 & 31.8 \\
Deforestation & 86.0 & 93.5 & 37.0 \\
\hline
\end{tabular}

(2012), distance to settlements generated from the landcover map, and distance to roads generated from the road network map. We also defined exclusion areas, where forest harvesting is legally forbidden: Natura 2000 protected areas, protected forests (ecologically significant forests), and all slopes above $25^{\circ}$ (FAO 1997). We processed all spatial factors with the obtained data on forest associations (districts) in a GIS and resampled them to the $30 \mathrm{~m}$ resolution of the land-cover maps (Quantum GIS Development Team 2013).

\section{Spatial Allocation Model}

We developed a spatially explicit forest cover change model in Dinamica EGO. The software is suitable for raster-based simulation of numerous land-cover changes on a high spatial resolution (Soares-Filho et al. 2002). It has already been applied to urban modeling, agricultural expansion, and forest dynamics (de Almeida et al. 2003;
Maeda et al. 2011; Kamusoko et al. 2013). Two different techniques were combined to spatially allocate forest cover changes: weights of evidence (WoE) and cellular automata (CA). While we applied the WoE method to generate a forest cover change transition probability map, we used the CA model to spatially allocate the changes to the forest cover on a $30 \mathrm{~m}$ resolution.

WoE is a Bayesian probability method, where individual influences of the spatial factors affecting a transition from one land cover to another are calculated from the historic frequency of that transition (Bonham-Carter 1994). We applied WoE as it is robust in handling missing data, and minimizing bias and subjectivity when evaluating different criteria (Hosseinali and Alesheikh 2008; Thapa et al. 2013). WoE values present the probability that a land-cover transition will occur for a particular spatial factor of change. In this case, the WoE values describe the relationship between a specific spatial factor and a forest cover change process. High values promote a particular 
transition, whereas lower values discourage them. Dinamica EGO enables the generation of a spatially explicit probability map, where each cell is described by the transition probability, based on WoE values. We calculated the probability map using the changes to the forest cover between 1989 and 2010 (Fig. 2) for both deforestation and forest expansion.

CA allocation models are effective at simulating spatial patterns of land change and are very adaptable; thus, they are able to simulate a wide variety of dynamic spatial processes (Wijesekara et al. 2014). CA models are bottomup models, where the landscape is defined as a grid of cells associated with a state, in this case land-cover types (Engelen et al. 1995). The cells change their states with each time step, according to the neighborhood defined by adjacent cells influencing the central cell, and transition rates that are the same for the whole landscape (Mitsova et al. 2011). The CA allocation model in Dinamica EGO consists of two stochastic allocation algorithms, the expander and the patcher. Both algorithms sort out the cells with highest transition probability in the initial land-cover map and then randomly select the calculated amount of cells using an internal stochastic selection procedure (Soares-Filho et al. 2002). The expander algorithm models the expansion of existing patches of a particular land cover (e.g., forest expansion on the account of adjacent abandoned grasslands). The patcher algorithm, on the other hand, generates new patches within a patch defined by a different land cover. This way, forest dynamics were modeled more realistically. Observed clear-cutting in the study area did not occur in the form of clearing the forest edge, but mostly as new non-forest patches within a larger patch of forest (Fig. 2). The expander function was attributed to forest expansion, whereas deforestation was assigned mostly ( $95 \%$ of the transition) to the patcher function.

By analyzing landscape metrics of changes between 1989 and 2010, we obtained the parameters of the spatial pattern of forest cover change: mean patch size and patch size variance (Gustafson 1998). We used them together with isometry to generate a more plausible pattern of spatial allocation of forest cover change (Table 2). The mean patch size and the variance define the size and its diversity of the new patches, and isometry describes how equal in shape and compact the new patches are. Isometry lower than 1 results in less equal and between 1 and 2 in more equal patches (Soares-Filho et al. 2002).

We used the 2010 map as the initial time step when allocating future scenarios. The model performed the allocation individually in each forest district, dividing forest harvesting among forest associations. Each forestry association manages forest harvesting in their own district, meaning that the estimated deforestation is distributed among districts and not only throughout the whole region.

\section{Model Validation}

We validated both the WoE transition potential and the CA allocation model. We applied the receiver operating characteristic (ROC) analysis to validate the WoE transition potential model. The ROC analysis is widely applied to assess the performance of raster-based spatial models generating a probability map (Pontius and Schneider 2001; Mas et al. 2013). ROC is a quantitative method to compare a reference binary variable with an index map, usually a continuous probability or suitability map (Mas et al. 2013; Pontius and Parmentier 2014). The binary variables in our example are the presence versus absence forest expansion and deforestation maps for the period 1989-2010. The index maps are the WoE transition potential maps for forest expansion and deforestation based on observations from the same time period. The resulting ROC curve indicates the rates of false and true positive, and its area under curve (AUC) summarizes the predictive power of the map compared to a random map (Mas et al. 2013). To ensure the independence of the selected spatial factors, we calculated the Cramer's Coefficient.

To validate the spatial allocation CA model, we calculated kappa simulation $\left(K_{\text {simulation }}\right)$, components of agreement and disagreement, and figure of merit. Similar to the Kappa statistic, $K_{\text {simulation }}$ is a coefficient of agreement between the simulated and observed land-cover changes. It, however, accounts for land-cover persistence and expresses only the agreement in the simulated and observed changes, instead of the comparison of the complete simulated and reference land-cover map (van Vliet et al. 2011). It indicates the agreement on the scale between -1 and 1 , where 1 means perfect agreement, 0 the level of agreement expected by chance, and -1 no agreement (van Vliet et al. 2011). Together with $K_{\text {simulation }}$, two other statistics are calculated: $\mathrm{K}_{\text {transition }}$ (agreement in quantity of land-cover changes) and $K_{\text {transloc }}$ (agreement in the allocation of land-cover changes). We performed the $K_{\text {simulation }}$ calculation comparing the observed and simulated 1989-2010 forest cover change map with the Map Comparison Kit (Visser and de Nijs 2006). Furthermore, we calculated the components of agreement and disagreement by performing a three map comparison (Pontius et al. 2011). The two components of agreement are persistent and changed areas that are simulated correctly. The components of disagreements are changes simulated as persistence, persistence simulated as changes and changes that were simulated wrong (different land-cover change simulated than observed). Finally, we calculated the figure of merit, a statistic indicating model accuracy in percent. It describes the ratio between the overlap of observed and simulated change and the union of the observed and simulated change (Pontius et al. 2007a, b). 
Table 2 Scenario characteristics

\begin{tabular}{|c|c|c|}
\hline & Alternative & BAU \\
\hline \multicolumn{3}{|l|}{ Drivers } \\
\hline Forest policy & $\begin{array}{l}\text { Immediate changes to the forest policy, oriented } \\
\text { toward desires of the wood processing industry }\end{array}$ & $\begin{array}{l}\text { The current forest policy, complete } \\
\text { implementation after } 2020\end{array}$ \\
\hline Wood processing industry & $\begin{array}{l}\text { Increase of the allowed harvested forests, } 66 \% \\
\text { increase of clear-cutting, increase of size of } \\
\text { areas that can be subject to clear-cutting }\end{array}$ & Increase of the allowed harvested forests \\
\hline \multicolumn{3}{|l|}{ Pressures } \\
\hline \multicolumn{3}{|l|}{ Amount of deforestation } \\
\hline Net annual increment (NAI) & $-13.2 \%$ until 2040 & $-13.2 \%$ until 2040 \\
\hline Forest growing stock & $+24.2 \%$ until 2040 & $+24.2 \%$ until 2040 \\
\hline Allowed forest harvesting per NAI & $42 \%(2010)$ to $85 \%$ (2040) & $42 \%(2010)$ to $85 \%(2040)$ \\
\hline \multicolumn{3}{|l|}{ Spatial pattern of forest cover change } \\
\hline \multirow[t]{2}{*}{ Mean patch size (MPS) } & Deforestation: 2.5 & Deforestation: $2.5,2.0$ after 2020 \\
\hline & Forest expansion: 2.0 & Forest expansion: 2.0 \\
\hline \multirow[t]{2}{*}{ MPS variance } & Deforestation: 5.5 & Deforestation: $5.5,5$ after 2020 \\
\hline & Forest expansion: 4.0 & Forest expansion: 4.0 \\
\hline \multirow[t]{2}{*}{ Isometry } & Deforestation: 0.9 & Deforestation: 0.9 \\
\hline & Forest expansion: 0.8 & Forest expansion: 0.8 \\
\hline \multirow[t]{2}{*}{ Transition rate } & $\begin{array}{l}\text { Deforestation: estimated annual deforestation, } \\
5 \% \text { clear felling potential }\end{array}$ & $\begin{array}{l}\text { Deforestation: Estimated annual deforestation, } \\
3 \% \text { clear felling potential }\end{array}$ \\
\hline & $\begin{array}{l}\text { Forest expansion: } 0.32 \% \text { annual transition rate } \\
\quad(1989-2010 \text { observation) }\end{array}$ & $\begin{array}{l}\text { Forest expansion: } 0.32 \% \text { annual transition rate } \\
\text { (1989-2010 observation) }\end{array}$ \\
\hline \multicolumn{3}{|l|}{ Response } \\
\hline \multirow[t]{2}{*}{ Current exclusion zones } & $\begin{array}{l}\text { Deforestation: slopes }>25^{\circ} \text {, protected areas, and } \\
\text { forests }\end{array}$ & $\begin{array}{l}\text { Deforestation: slopes }>25^{\circ} \text {, protected areas, and } \\
\text { forests }\end{array}$ \\
\hline & Forest expansion: grasslands in protected areas & Forest expansion: grasslands in protected areas \\
\hline $\begin{array}{l}\text { Landslide risk reduction scenarios: } \\
\text { high-risk exclusion zones }\end{array}$ & $\begin{array}{l}\text { Areas with }>50 \% \text { landslide susceptibility in the } \\
90 \mathrm{~m} \text { distance from roads and settlements }\end{array}$ & $\begin{array}{l}\text { Areas with }>50 \% \text { landslide susceptibility in the } \\
90 \text {-m distance from roads and settlements }\end{array}$ \\
\hline
\end{tabular}

\section{Scenario Development}

We conducted 13 semi-structured interviews and group meetings with forestry, environmental, and risk experts on the local level (forest association), as well as on the regional level (county) in July and September 2012. Interviews contained questions on observed and expected future forest cover changes, their consequences and importance; influence of socio-economic development; the role of different levels of decision-making (local, regional, national); and also possible effects of external driving forces, such as political changes. We adopted the DriversPressures-State-Impact-Response (DPSIR) framework (EEA 1999) to translate the expert knowledge to a conceptual deforestation model (Fig. 3). Together with the experts, we identified each part of the DPSIR, simulating the cause-response framework of planning and management of forest harvesting in the region. This enabled us to structure the relationship between the driving forces of deforestation with their consequences. We later used the
DPSIR model to develop forest cover change scenarios and the allocation model. Together with the experts, we defined the drivers, pressures, and response parameters of the conceptual model (Fig. 3) in advance (Table 2). The state and impact parts were a result of subsequent modeling and presented the resulting deforestation and the potential landslide risk.

Based on the conceptual deforestation model (Fig. 3), we developed two forest cover change scenarios: Business as Usual (BAU) and Alternative scenario (ALT). In both scenarios, we modeled two processes of forest cover change: deforestation and forest expansion. Deforestation was defined as a land-cover transition from forest to nonforest, as a result of clear-cutting. In the study area, clearcutting is characterized as the removal of all trees in a predefined and limited area, usually smaller than 3 ha. Although it is not a prevailing forest management practice in Romania, it is the main focus of the developed scenarios. Deforestation can increase the occurrence of landslides, acknowledged both by the involved experts and literature 
Fig. 3 Drivers-pressuresstate-impact-response conceptual deforestation model
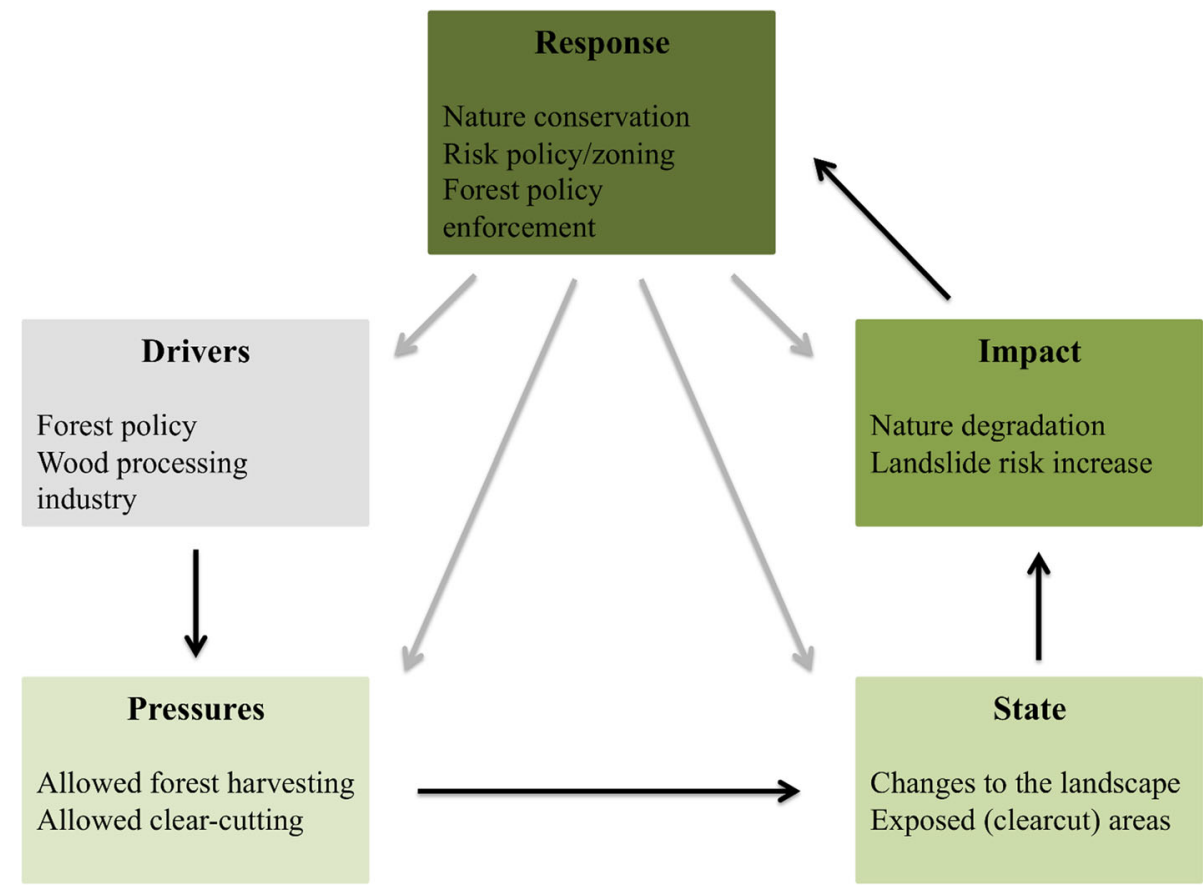

(Schmidt et al. 2001; Glade 2003). Following expert interviews, we developed a simplified model that calculates scenario-based deforestation transition rates, resulting in the demand for forest areas in spatial terms. We used a simplified annual deforestation estimation model:

$d_{t}=\frac{f_{t} \times n_{t} \times a_{t} \times c_{t}}{g_{t}}$,

where for the year $t, d_{t}$ is the estimated annual deforestation in ha, $f_{t}$ the allowed forest harvesting defined as percentage of the net annual increment, $n_{t}$ the net annual increment in $\mathrm{m}^{3} / \mathrm{ha}, a_{t}$ forest areas in ha, $c_{t}$ the clear-cutting potential in $\%$ of total forest harvesting, $g_{t}$ the forest growing stock in $\mathrm{m}^{3} / \mathrm{ha}$.

In our conceptual model, the forest policy and wood processing industry influence the allowed forest harvesting (Fig. 3; Table 2). They are based on the proposed outlook for the development of Romanian forest resources (Schelhaas et al. 2006). The allowed forest harvesting Pressure has the same biophysical assumptions in both scenarios: an increase of the growing stock (total standing tree volume) and the decrease of the net annual increment (average annual volume increase) per hectare (Table 2). Forest data for Buzau County for the year 2010 served as a starting point: the mean growing stock was $217 \mathrm{~m}^{3}$ per hectare, and the mean net annual increment was $6 \mathrm{~m}^{3}$ per hectare. The maximum annual clear-cutting potential was estimated to be $3 \%$ of the total amount of allowed forest harvesting (Bohateret 2012), even though the potential can vary among different forest types. This potential defines the limit of allowed forest harvesting through clear-cutting and is set as a threshold for protection and sustainable management of Romanian forests (Giurgiu 2004). Differences in growing stock, net annual increment, and clear-cutting potential across the landscape were not taken into account, as the data on spatial variation of forest types, quality, and age were not available. Therefore, we used mean values for the whole Buzau Subcarpathians. The two scenarios differ in the amount and spatial pattern of clear-cutting. The BAU scenario follows existing policy, thus, maintaining the potential of clear-cutting at $3 \%$ of the total forest harvesting. The involved experts identified the existing policy as sustainable. Its problems are related to its implementation: field control of allowed clear-cuts is currently difficult due to lack of personnel, funds, and institutional issues, resulting in excessive clear-cutting in sizes above the legal $3 \mathrm{ha}$. Therefore, we applied a time lag of 10 years in this scenario, where the values for the size of clear-cuts remain the same until 2020. This way we simulated the successful implementation of the current policy after 10 years from 2010 on one side, and compensation in form of smaller clear-cut areas due to excessive clear-cuts until 2020. Thus, the mean size of clear-cut patches after 2020 was 2 ha, instead of 2.5 ha as observed between 1989 and 2010 (Table 2). The ALT was oriented toward the desired goals of investors in the wood harvesting and processing industry. Involved experts revealed that investors in the forestry sector support the increase of the allowed clear-cutting. This would enable easier, faster, and less costly exploitation of forest resources, especially with the existent forest 
road network. Thus, in the ALT, the percentage of clearcutting in the total forest harvesting rose up to $5 \%$, with the remaining larger mean size of clear-cut patches (2.5 ha). Finally, we modeled two additional scenarios: an implemented simplified risk policy for the BAU and ALT scenario. Here, we excluded all areas highly susceptible to landslides in the $90 \mathrm{~m}$ vicinity of roads and settlements as explained later in the Landslide risk section.

Additionally, we modeled future forest expansion. We defined it as a change from non-forest to forest from grasslands or other vegetation to forest. This process was taken into account in both scenarios, as we wanted to study the potential positive impact of forest expansion on landslide risk and compare it to the impact of deforestation. The transition rate for forest expansion was the same for both scenarios. It followed the observed trends between 1989 and 2010, simulating more long-term forest expansion trends instead of the more recent ones. We modeled forest expansion only on the basis of past remote-sensing observations and the influence of the spatial factors of forest expansion as described later. Therefore, forest expansion was not subject to any forest harvesting scenarios. Nonforest areas that were transformed into forest areas during the run of the model were not considered for deforestation. According to Romanian legislation, these areas will not have reached the appropriate age for exploitation in the modeled time span (Parlamentul României 1996). They can be considered in calculating the allowed forest harvesting after 10 years (FAO 1997).

\section{Landslide Risk}

We overlaid the model outputs with a landslide susceptibility map for Buzau County (Hussin et al. 2013; Zumpano et al. 2014) in a GIS (Fig. 4a). Landslide susceptibility is the probability of spatial occurrence of known landslides under a set of environmental characteristics (Glade and Crozier 2005; Guzzetti et al. 2006). Susceptibility maps can therefore be used to predict the locations of future landslides; based on an assumption, they will occur on the same conditions as they did in the past (Guzzetti et al. 2005; Petschko et al. 2014). This way, they are useful when a landslide hazard map is either missing or incomplete, as is in this case. Therefore, we used these data as a proxy for landslide risk. The used landslide susceptibility map had been generated using 8 variables: altitude, aspect, planar curvature, profile curvature, slope, internal relief, soil, and land cover (Hussin et al. 2013; Zumpano et al. 2014). We assessed each scenario in terms of occurrence of deforestation in landslide susceptibility classes. Finally, we modeled two additional scenarios where we simulated both scenarios again with high-landslide risk areas excluded. As a proxy for high-landslide risk in this data-poor area, we defined areas with above $50 \%$ landslide susceptibility in the distance of $90 \mathrm{~m}$ of significant elements at risk (settlements, roads, Fig. 4b). We compared the results with the two scenarios without landslide information, to identify the possible costs of this simplified risk policy. We achieved this by observing the occurrence of deforestation for both scenarios in slope classes and distance to roads, as proxies for accessibility.

\section{Results}

\section{Weight of Evidence and Forest Cover Change Probability}

The WoE varied substantially between deforestation and forest expansion (Fig. 5). The probability for deforestation decreased with the distance from roads, whereas it slightly increased for forest expansion (Fig. 5a). The probability for deforestation decreased with increasing slopes and substantially increased for forest expansion (Fig. 5b). The probability map for forest expansion showed that remote areas on higher altitudes and steeper slopes had a higher probability for forest expansion (Fig. 6a). More accessible grasslands and pastures on gradual slopes and lower altitude were therefore less susceptible to abandonment and forest expansion. The probability map for deforestation showed that the role of altitude is less significant, and factors like distance to roads and slopes are more important (Fig. 6b).

\section{Simulated Scenarios}

The 2040 scenarios show all locations where deforestation was projected to occur during the 30 -year model run. For example, if an area had experienced deforestation in the earlier years of the run, this area was still portrayed as deforested in 2040. This way, we demonstrated the full spatial distribution of the landscape affected by deforestation. There were no considerable differences in the spatial distribution of forest cover changes between the two scenarios (Fig. 7). This is because they were both based on identical spatial factors and transition probability maps (Fig. 6). The two scenarios did, however, differ in the total 2010 forest areas subject to deforestation until 2040: $2.2 \%$ in the Alternative and $1.3 \%$ in the BAU scenario (Table 3). The amount of forest expansion was $99.93 \mathrm{~km}^{2}$, resulting in an $8 \%$ increase of forest cover in the Alternative, and an $8.8 \%$ increase in the BAU scenario. For both scenarios, this meant a $14.3 \%$ decrease in grasslands. 
Fig. 4 a Landslide susceptibility map (modified from Hussin et al. 2013 and Zumpano et al. 2014) and b areas excluded for the additional model run: areas over $50 \%$ susceptibility within a 90-m distance from settlements and roads
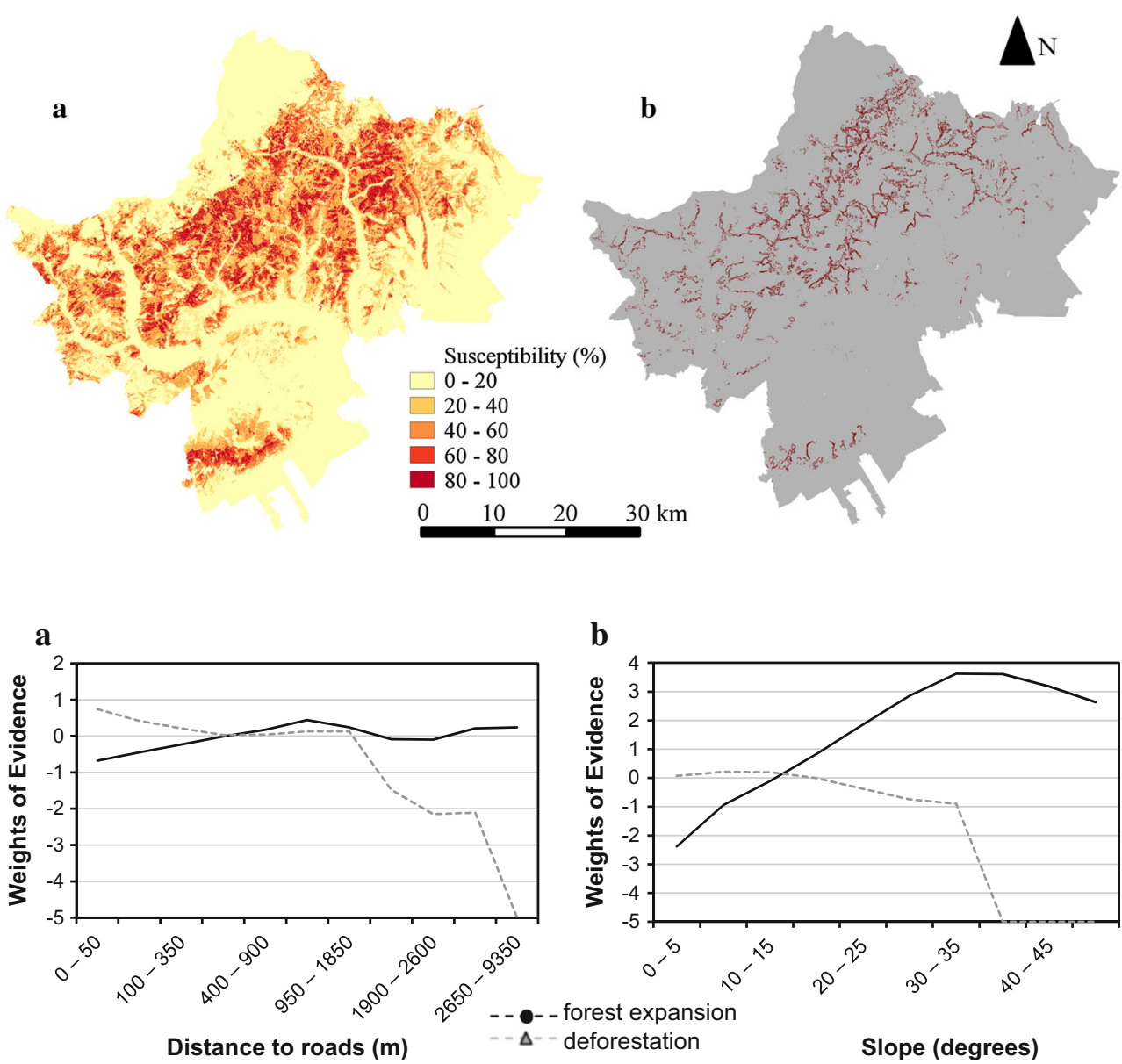

Fig. 5 Weights of Evidence values for a distance to roads and $\mathbf{b}$ slopes
Fig. 6 Transition probability maps for a forest expansion and b deforestation for the year 2010, ranging from 0 (low) to 1 (high)

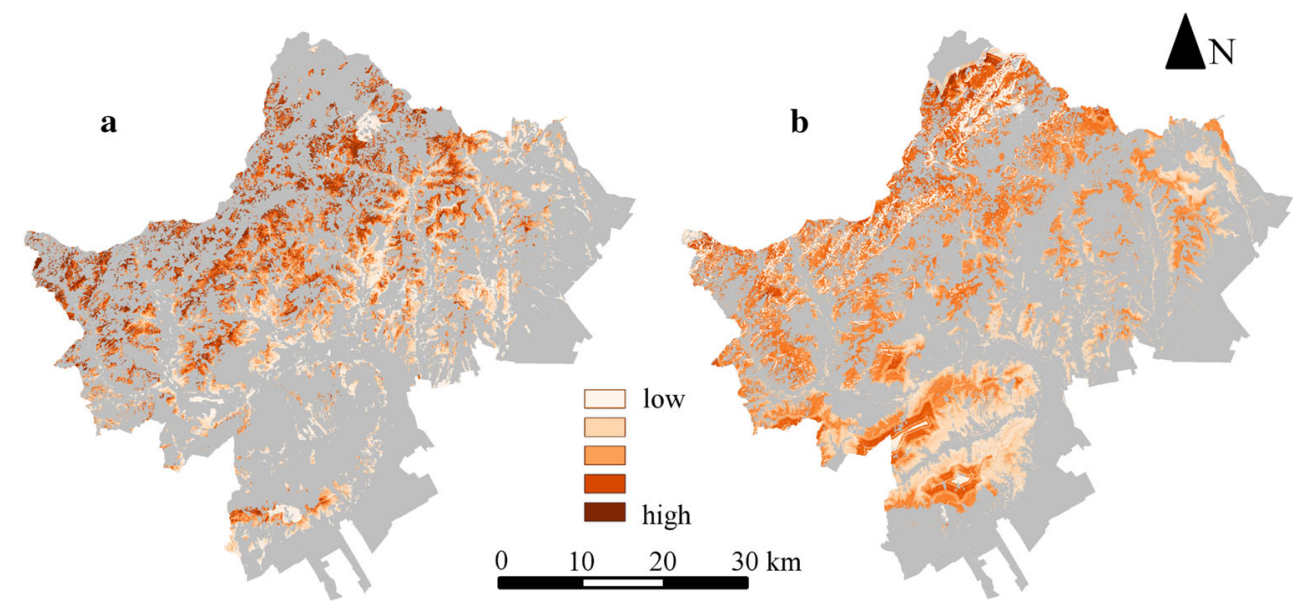

\section{Model Performance}

The ROC curve and AUC indicate the projection accuracy of the forest cover transition probability maps for both simulated transitions and are presented in Fig. 8. The projection accuracy was higher for the forest expansion probability map compared to the deforestation probability map. Both transition probability maps exhibited a significantly different predictive power compared to a random map. Moreover, all spatial factors had a Cramer coefficient below 0.25 , with 0.5 being a threshold under which the spatial factors are independent (de Almeida et al. 2003).

The performance of the spatial allocation model was assessed both in terms of agreement in quantity and 
Fig. 72040 forest cover scenarios: a Alternative, b BAU; scenarios considering landslide risk: c Alternative, d BAU

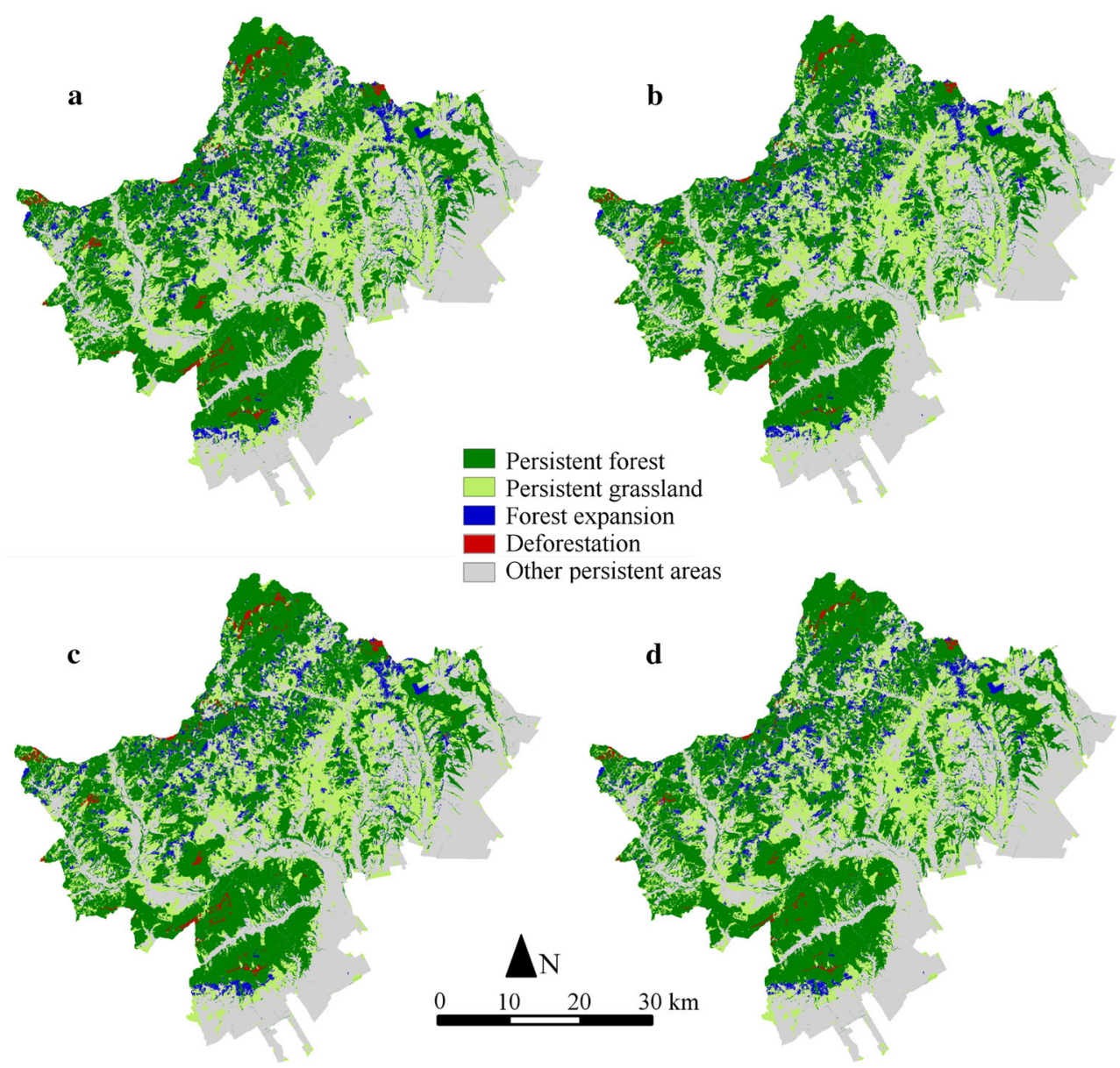

Table 3 Distribution of forest cover change scenarios and baseline among landslide susceptibility classes

\begin{tabular}{|c|c|c|c|c|c|c|}
\hline \multirow[t]{2}{*}{ Susceptibility (\%) } & \multicolumn{3}{|l|}{ Scenarios (ha) (\%) } & \multicolumn{3}{|c|}{ Baseline $2010\left(\mathrm{~km}^{2}\right)(\%)$} \\
\hline & Deforestation alternative & Deforestation BAU & Forest expansion & Total area & Forest & Non-forest areas \\
\hline $0-20$ & 980.7 (45.9) & $607.7(47.4)$ & $1844.7(18.5)$ & $1172.7(48.4)$ & $364.3(37.1)$ & $808.2(56.2)$ \\
\hline $20-40$ & $673.8(31.5)$ & $399.5(31.1)$ & $1407.0(14.1)$ & $534.2(22.1)$ & $350.6(35.7)$ & $183.1(12.7)$ \\
\hline $40-60$ & $374.7(17.5)$ & $219.8(17.1)$ & $1839.7(18.4)$ & 328.7 (13.6) & $203.4(20.7)$ & $125.3(8.7)$ \\
\hline $60-80$ & $105.7(4.9)$ & $53.8(4.2)$ & $2344.4(23.4)$ & $216.9(9.0)$ & $59.5(6.1)$ & $158.0(10.9)$ \\
\hline $80-100$ & $2.9(0.1)$ & $1.9(0.1)$ & $2558.2(25.6)$ & $168.5(7.0)$ & $3.2(0.3)$ & $165.3(11.5)$ \\
\hline Total & 2138 & 1283 & 9993 & 2421 & 981 & 1440 \\
\hline
\end{tabular}

The values for the scenarios are in ha and $\%$ of the total forest cover change process, the values for the baseline are in $\mathrm{km}^{2}$ and $\%$

location and is summarized in Table 4. The $K_{\text {simulation, }}$ $K_{\text {Transition }}$, and $K_{\text {Transloc }}$ of the spatial allocation model were all well above 0 . The model so performs better as expected by chance, however, still demonstrates a level of uncertainty described by the character of these agreement metrics (van Vliet et al. 2011). The components of agreement together with the figure of merit indicate a lower predictive power of the model in terms of exact pixel locations.
Moreover, the simulated changes (correct and errors) are minor compared to the correctly simulated persistence.

\section{Landslide Risk}

The vast majority of deforestation was modeled in areas with low landslide susceptibility, as opposed to forest expansion (Table 3). In total, 483 ha in the Alternative run 


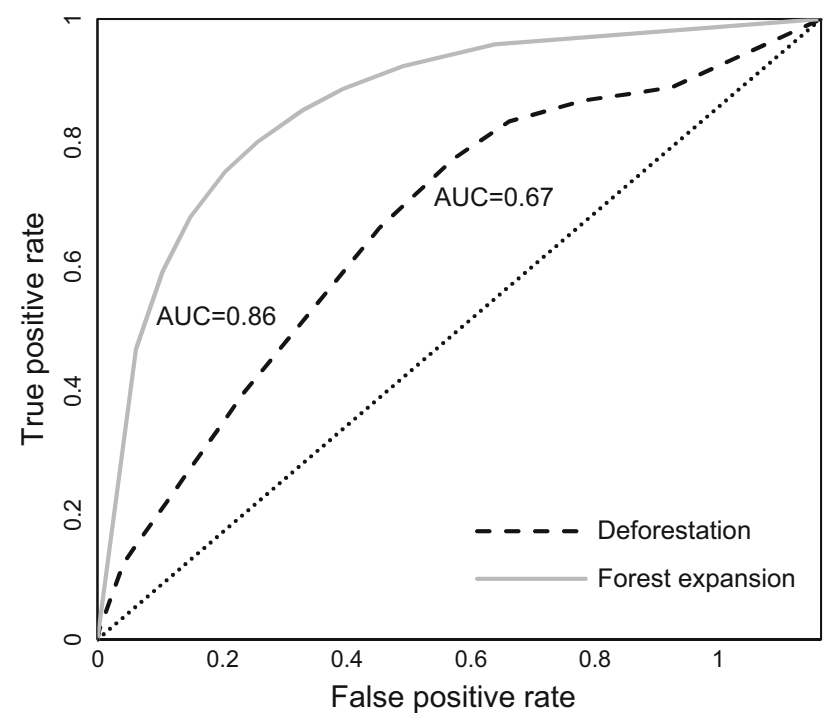

Fig. 8 Projection accuracy of the Weights of Evidence forest cover transition probability maps indicated by ROC curves and AUC values for forest expansion and deforestation

Table 4 Model performance described by the metrics of Kappa simulation, components of agreement and disagreement, and figure of merit

\begin{tabular}{lc}
\hline Kappa simulation & Agreement \\
\hline$K_{\text {simulation }}$ & 0.23 \\
$K_{\text {transition }}$ & 0.95 \\
$K_{\text {transloc }}$ & 0.24 \\
\hline Components of agreement and & $\%$ of the whole \\
disagreement & land-cover map \\
\hline Agreement & \\
Persistence simulated correctly & 91.4 \\
Change simulated correctly & 1.2 \\
Disagreement & \\
Change simulated as persistence & 3.8 \\
Persistence simulated as change & 3.6 \\
Change simulated as wrong change & 0.0 \\
Figure of merit & 14.2 \\
\hline
\end{tabular}

and 276 ha in the BAU scenario were projected to occur in areas with a landslide susceptibility over $40 \%$. The amount of deforestation remained the same in model runs with excluded highly susceptible areas, with a slightly different spatial distribution (Fig. 7c and d). There are two main reasons behind the majority of deforestation being projected in areas with low susceptibility. First, the WoE and consequent deforestation probability maps promoted deforestation on areas with lower slopes (Figs. 5b and 6). Secondly, non-forest areas had a higher likelihood of being characterized with higher landslide susceptibility than forest areas. In our example, more than $80 \%$ of forests were defined with a susceptibility value below $50 \%$ (Table 3). This means that a landslide would be less likely to occur on a forested area, as opposed to a non-forested area with similar environmental characteristics (slope, lithology). This is not surprising, as evidence shows the positive influence of roots mechanically reinforcing soils in forested landscapes (Schmidt et al. 2001).

We demonstrated the impact of implementing a risk policy by observing the changes in the distribution in distance and slope classes in the two additional scenarios (Fig. 9). We did not observe any evidence on increasing the distance of clear-cuts from roads. There were gains and losses in both the near and more distant 10-quantile classes (Fig. 9a). The impact of the risk policy is more significant when looking at differences to distribution in slope classes. In the ALT, more deforestation was projected on steeper areas (above $15^{\circ}$ ), whereas in the BAU scenario, substantially more changes occurred in the slope class between 5 and 10 degrees (Fig. 9b). Considering both distribution differences, the accessibility of clear-cuts decreased in the Alternative and did not change in the BAU scenario. Thus, the implemented risk policy could result in additional costs to forest exploitation when raising the clear-cut limit (Alternative) and no costs in the BAU clear-cut quantities.

\section{Discussion and Conclusion}

Current and past forest changes in the Carpathian region are well understood. The complex causes of forest cover changes are well studied and focus among others on changes to the ownership, forest policy, and emergence of private forestry and wood processing industry (Ioras and Abrudan 2006; Griffiths et al. 2012; Munteanu et al. 2014; Griffiths et al. 2014). Nevertheless, there is a lack of future projections on how continuing socio-economic and policy changes can affect the forest cover in a region in socioeconomic transition, such as the Carpathians. In this study, we generated future forest cover scenarios in a region in the Romanian Carpathians. These scenarios were based on identified possible changes to current forest policy. We then assessed potential future changes to landslide risk and the effect of a risk mitigation policy.

The deforestation estimation part of the model differs substantially from other similar scale forest cover change studies. It is based on the identified changes in regards to the allowed forest harvesting and clear-cutting. This is not the case in several other studies, where estimates are based on observed historic forest cover transition rates: examples range among others from Brazil (Yanai et al. 2012), Indonesia (Fuller et al. 2011), to Laos (Kamusoko et al. 2013). These examples, however, offer insight into the 
Fig. 9 Difference in distribution of deforestation taking into account risk information in a distance 10-quantile classes and $\mathbf{b}$ slope classes

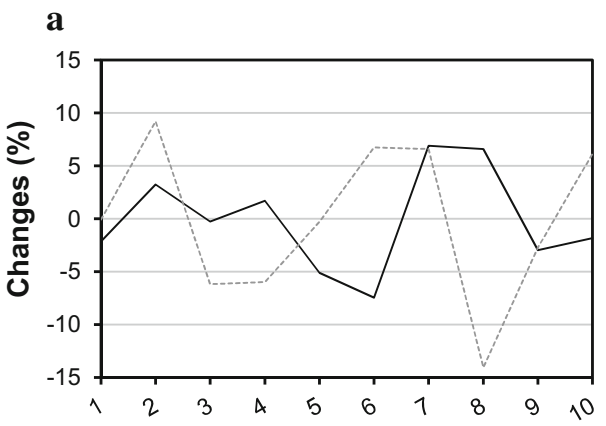

b

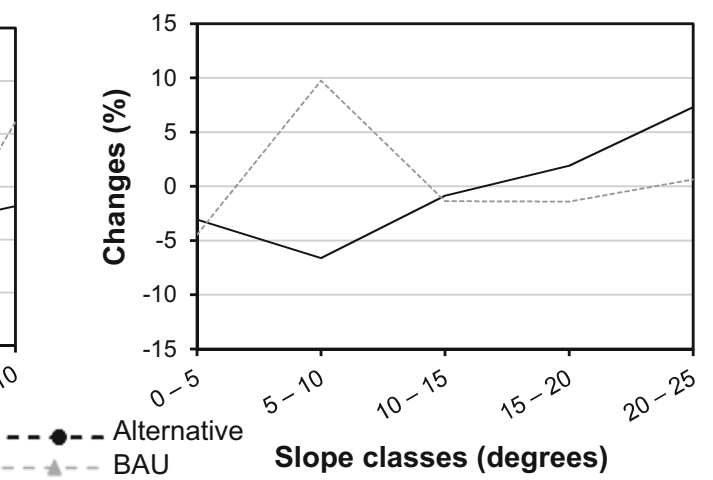

spatial allocation procedure and the identification of spatial factors (elevation, slope, distance to settlements, roads). The process of forest expansion was based on remotesensing observations between 1989 and 2010. Forest expansion in the Carpathians is a long-term process similar to other European mountain areas (Mather 2001; Kozak et al. 2007a; Munteanu et al. 2014). Therefore, we chose a longer period to simulate a long-term forest expansion trend. The possible different rates of past forest expansion were thus not considered in the scenarios. Some parts of the Romanian Carpathians did, however, experience different rates of forest expansion due to different land abandonment rates in the past decades (Griffiths et al. 2013).

It remains difficult to assess the performance of landcover change models, as they are calibrated with past observations, particularly when dealing with the location of changes and not just their quantity (Veldkamp and Lambin 2001). Nevertheless, we consider the performance of the modeling framework as acceptable due to several reasons. The WoE model for both transitions exhibits a satisfactory performance as indicated by the ROC curve and AUC value. The spatial allocation model is also performing significantly better compared to a random map and is comparable with similar land change models developed in Dinamica EGO (Soares-Filho et al. 2002; Maeda et al. 2011; Kamusoko et al. 2013; Thapa et al. 2013). When looking at the Kappa simulation statistics, the model performs significantly different when compared to a random map (van Vliet et al. 2011). Nevertheless, the model exhibits a wide range of uncertainty when simulating the location of future changes, as described by the figure of merit metric. It has, however, been shown that applications in study areas where the observed net changes are minor, tend to have a lower figure of merit (Pontius et al. 2007a). In this example, the majority of the study area is indeed expected not to change. The calculated scenario amounts can be considered relatively insignificant when compared to the whole study area. Furthermore, previous applications of the CA allocation in Dinamica EGO have shown, that the model performs very well when simulating the spatial pattern of land-cover changes. This is characterized by relatively high success rates of simulated land-cover changes in the multi-pixel neighborhood of the observed reference pixel, compared to the success rate of simulating exact locations (Hagen 2003; Maeda et al. 2010). Nevertheless, looking at the exact locations of simulated change should be done with care, as the uncertainty of the spatial allocation model is aggregated with the uncertainties in the input land-cover and susceptibility maps.

Several studies have addressed the influence of future land-cover changes on risk, either through identifying risk hotspots (Promper et al. 2014) or overlaying the scenarios with a hazard map (Barredo and Engelen 2010). Due to lack of data on landslide hazard or risk, we used a landslide susceptibility map. Landslide susceptibility analysis has already been used to study the influence of past and current land cover (Chitu et al. 2015; Reichenbach et al. 2015). Still, landslide data used for generating the susceptibility map could ignore landslides occurring in forests. This could result in underestimation of susceptibility values in forests and overestimation of susceptibility values on nonforest areas. The projected amount of deforestation in areas with higher landslide susceptibility cannot be considered insignificant, as the Subcarpathians are a relatively densely populated area. However, as most of the forest expansion was projected on areas with higher landslide susceptibility, we expect an overall regional decrease in landslide susceptibility. These results are not surprising, as reforestation has already been acknowledged to improve slope stability and could be considered as a risk reduction measurement (Phillips and Marden 2005). Our study did not only confirm that it also quantified these positive effects of forest expansion in terms of areas subject to a decrease in landslide susceptibility. This way, the results can be used for evaluating the impact of forest management on landslide risk. Different landslide risk reduction measures can be 
prioritized using the results: areas with prioritized deforestation regulation or planned reforestation. Moreover, the methodology itself could be further elaborated in the future by introducing additional extreme scenarios such as largescale forest fires (Reichenbach et al. 2014).

The CA allocation algorithm simulates the choice of plots (cells) subject to deforestation and can explain the influence of the implemented risk policy. In the case of an excluded area (due to high susceptibility), the changes occurred in the nearest cells with a similar deforestation probability. This did not result in evident changes to the distance of deforestation from roads, however, could still result in deforestation on steeper slopes. Therefore, the evidence on higher costs related to the accessibility of the clear-cuts is stronger in the case of slopes and less evident in the case of the distance.

Deforestation could also lead to other consequences besides the potential changes to landslide risk. Among others, it might affect habitat fragmentation and changes to landscape connectivity (Körner et al. 2005; Millenium Ecosystem Assessment 2005). This is important, as the Buzau Subcarpathians are characterized by a high frequency of European large carnivores such as the brown bear (Ursus arctos) and the wolf (Canis lupus) (van Maanen et al. 2006). Thus, we suggest additional research on analyzing the impact of deforestation on biodiversity. Forest expansion can also have a wide variety of other consequences, e.g., it can be beneficial for bird and large mammal habitats (Baur et al. 2006; Bowen et al. 2007; Navarro and Pereira 2012). Forest expansion can also have detrimental effects. Several studies have emphasized the influence of forest expansion and loss of grasslands on ecosystem services provisioning: loss of high-value nature grasslands, landscape diversity, and potential loss of important habitats (MacDonald et al. 2000; Fischer et al. 2008; Zimmermann et al. 2010).

In this study, we focused on plausible scenarios; however, we could also study less likely, extreme scenarios. First example is scenarios where forest management is following only market demands, thus promoting less costly large-scale clear-cutting (Thapa et al. 2013). Secondly, possible influence of new road infrastructure could be studied (Maeda et al. 2011; Kamusoko et al. 2013). Furthermore, our scenarios did not take into account illegal logging, a significant issue in the Carpathian region (Griffiths et al. 2012; 2014). Due to lack of data and the randomness of the phenomena, we believe other approaches such as agent-based modeling should address this issue. Finally, we could investigate radical political changes, similar to the events after 1989 (ownership reforms, introduction of a market economy), or possible shocks as a dramatic wood demand due to bioenergy policy changes. The level of plausibility of both developed scenarios (both are likely to happen) also leads to seemingly small differences between the two scenarios. Our results, however, showed that already allowing an increase in amount and size of clear-cutting could lead to significant changes to landslide risk. Moreover, we showed that avoiding this risk could lead to higher costs to forest harvesting in case of the increase in clear-cutting. Therefore, we believe that our approach is especially significant in providing information on possible changes to landslide risk and the effect of risk related policies.

Scenarios are not exact projections of future states of the environment (Abildtrup et al. 2006). Nevertheless, they can serve as a valuable tool to study policy decisions, leading to improved knowledge on forest exploitation and protection. Even though the uncertainties of data and the model have to be taken into account, the results suggest most likely areas where deforestation might occur in the future. Therefore, they could be prioritized as locations, where risk reduction measures need to be considered (reforestation, technical works). Moreover, improving the model with better data-especially in terms of landslide risk-could lead to more precise results, enabling the support and improvement of decision-making in forest management.

The use of scenarios as a methodology for studying land-cover changes has been studied thoroughly on different scales and in different areas. This study, however, presents a new approach integrating qualitative methods such as interviews, with geospatial technologies such as GIS and spatial simulation. The developed scenarios were based on the understanding of the system of forest management and were not based solely on extrapolating past trends. Moreover, the scenarios are spatially explicit, enabling the identification of the spatial pattern of change and possible critical areas of forest cover change. Another innovative aspect of the study is that it analyzes possible changes to landslide risk, as a consequence of future forest cover change. Finally, this study contributes to the understanding of future environmental consequences of today's decisions in the field of forest and land-use management in the Carpathian region.

Acknowledgments This work is a part of the CHANGES project (Changing hydro-meteorological risks-as Analysed by a New Generation of European Scientists), a Marie Curie Initial Training Network, funded by the European Community's 7th Framework Programme FP7/2007-2013 under Grant Agreement No. 263953. The authors would also like to thank Roxana Ciurean, Veronica Zumpano, and Mihai Micu for their extensive help.

\section{References}

Abildtrup J, Audsley E, Fekete-Farkas M et al (2006) Socio-economic scenario development for the assessment of climate change impacts on agricultural land use: a pairwise comparison 
approach. Environ Sci Policy 9:101-115. doi:10.1016/j.envsci. 2005.11.002

Bălteanu D, Popovici EA (2010) Land use changes and land degradation in post-socialist Romania. Romanian J Geogr 54:95-105

Barredo JI, Engelen G (2010) Land use scenario modeling for flood risk mitigation. Sustainability 2:1327-1344. doi:10.3390/ su2051327

Baumann M, Kuemmerle T, Elbakidze M et al (2011) Patterns and drivers of post-socialist farmland abandonment in Western Ukraine. Land Use Policy 28:552-562. doi:10.1016/j.landuse pol.2010.11.003

Baur B, Cremene C, Groza G et al (2006) Effects of abandonment of subalpine hay meadows on plant and invertebrate diversity in Transylvania, Romania. Biol Conserv 132:261-273. doi:10. 1016/j.biocon.2006.04.018

Björnsen Gurung A, Bokwa A, Chełmicki W et al (2009) Global change research in the Carpathian mountain region. Mt Res Dev 29:282-288. doi:10.1659/mrd.1105

Bohateret VM (2012) Readjusting Romania's forestry policy with a view to the year 2050. J Settl Spat Plan 1:27-42

Bonham-Carter G (1994) Geographic information systems for geoscientists: modelling with GIS. Pergamon, Oxford, New York

Bowen ME, McAlpine CA, House APN, Smith GC (2007) Regrowth forests on abandoned agricultural land: a review of their habitat values for recovering forest fauna. Biol Conserv 140:273-296. doi:10.1016/j.biocon.2007.08.012

Chemini C, Rizzoli A (2003) Land use change and biodiversity conservation in the Alps. J Mt Ecol 7:1-7

Chitu Z, Istrate A, Adler M-J et al (2015) Comparative study of the methods for assessing landslide susceptibility in Ialomiţa Subcarpathians, Romania. In: Lollino G, Giordan D, Crosta GB et al (eds) Engineering Geology for Society Territory, vol 2. Springer International Publishing, pp 1205-1209

De Almeida CM, Batty M, Vieira Monteiro AM et al (2003) Stochastic cellular automata modeling of urban land use dynamics: empirical development and estimation. Comput Environ Urban Syst 27:481-509. doi:10.1016/S01989715(02)00042-X

Deshler D (1987) Techniques for generating futures perspectives. New Dir Adult Contin Educ 1987:79-92. doi:10.1002/ace. 36719873609

EEA (1999) Environmental indicators: typology and overview. European Environment Agency, Copenhagen

Engelen G, White R, Uljee I, Drazan P (1995) Using cellular automata for integrated modelling of socio-environmental systems. Environ Monit Assess 34:203-214. doi:10.1007/ BF00546036

Falcucci A, Maiorano L, Ciucci P et al (2008) Land-cover change and the future of the Apennine brown bear: a perspective from the past. J Mammal 89:1502-1511. doi:10.1644/07-MAMM-A-229.1

FAO (1997) Issues and Opportunities in the Evolution of Private Forestry and Forestry Extension in Several Countries with Economies in Transition in Central and Eastern Europe. Food and Agriculture Organization of the United Nations, Rome

Fischer M, Rudmann-Maurer K, Weyand A, Stöcklin J (2008) Agricultural land use and biodiversity in the Alps. Mt Res Dev 28:148-155. doi:10.1659/mrd.0964

Fuller DO, Hardiono M, Meijaard E (2011) Deforestation projections for carbon-rich peat swamp forests of Central Kalimantan, Indonesia. Environ Manag 48:436-447. doi:10.1007/s00267011-9643-2

Ghimire S, Higaki D, Bhattarai T (2013) Estimation of soil erosion rates and eroded sediment in a degraded catchment of the Siwalik Hills, Nepal. Land 2:370-391. doi:10.3390/land2030370
Giupponi C, Ramanzin M, Sturaro E, Fuser S (2006) Climate and land use changes, biodiversity and agri-environmental measures in the Belluno province, Italy. Environ Sci Policy 9:163-173. doi:10.1016/j.envsci.2005.11.007

Giurgiu V (2004) Gestionarea durabilă a pădurilor României. Silvologie, vol III B. The Publishing House of the Romanian Academy, Bucharest

Glade T (2003) Landslide occurrence as a response to land use change: a review of evidence from New Zealand. Catena 51:297-314. doi:10.1016/S0341-8162(02)00170-4

Glade T, Crozier MJ (2005) The nature of landslide hazard impact. In: Glade T, Anderson M, Crozier MJ (eds) Landslide hazard risk. Wiley, New York, pp 41-74

Griffiths P, Kuemmerle T, Kennedy RE et al (2012) Using annual time-series of Landsat images to assess the effects of forest restitution in post-socialist Romania. Remote Sens Environ 118:199-214. doi:10.1016/j.rse.2011.11.006

Griffiths P, Müller D, Kuemmerle T, Hostert P (2013) Agricultural land change in the Carpathian ecoregion after the breakdown of socialism and expansion of the European Union. Environ Res Lett 8:045024. doi:10.1088/1748-9326/8/4/045024

Griffiths P, Kuemmerle T, Baumann M et al (2014) Forest disturbances, forest recovery, and changes in forest types across the Carpathian ecoregion from 1985 to 2010 based on Landsat image composites. Remote Sens Environ 151:72-88. doi:10. 1016/j.rse.2013.04.022

Gustafson EJ (1998) Quantifying landscape spatial pattern: what is the state of the art? Ecosystems 1:143-156. doi:10.1007/ s100219900011

Guzzetti F, Reichenbach P, Cardinali M et al (2005) Probabilistic landslide hazard assessment at the basin scale. Geomorphology 72:272-299. doi:10.1016/j.geomorph.2005.06.002

Guzzetti F, Reichenbach P, Ardizzone F et al (2006) Estimating the quality of landslide susceptibility models. Geomorphology 81:166-184. doi:10.1016/j.geomorph.2006.04.007

Hagen A (2003) Fuzzy set approach to assessing similarity of categorical maps. Int J Geogr Inf Sci 17:235-249. doi:10.1080/ 13658810210157822

Hessel R, Messing I, Liding C et al (2003) Soil erosion simulations of land use scenarios for a small Loess Plateau catchment. Catena 54:289-302. doi:10.1016/S0341-8162(03)00070-5

Hosseinali F, Alesheikh AA (2008) Weighting spatial information in GIS for copper mining exploration. Am J Appl Sci 5:1187-1198. doi:10.3844/ajassp.2008.1187.1198

Hussin H, Zumpano V, Sterlacchini S et al (2013) Comparing the predictive capability of landslide susceptibility models in three different study areas using the Weights of Evidence technique. EGU General Assembly Conference Abstracts, Vienna, p 12701

INSSE (2013) Romanian National Institute of Statistics Data Portal. http://www.insse.ro/. Accessed 11 May 2013

Ioras F, Abrudan I (2006) The Romanian forestry sector: privatisation facts. Int For Rev 8:361-367. doi:10.1505/ifor.8.3.361

Kamusoko C, Wada Y, Furuya T et al (2013) Simulating future forest cover changes in Pakxeng district, Lao people's democratic republic (PDR): implications for sustainable forest management. Land 2:1-19. doi:10.3390/land2010001

Knorn J, Kuemmerle T, Radeloff VC et al (2012) Forest restitution and protected area effectiveness in post-socialist Romania. Biol Conserv 146:204-212. doi:10.1016/j.biocon.2011.12.020

Körner C, Ohsawa M, Spehn E et al (2005) Mountain systems. In: Hassan R, Scholes R, Ash N (eds) Ecosystem and human well being: current state and trends: findings of the Conditions and Trends working group. Millennium Ecosystem Assessment, pp $681-716$ 
Kozak J, Estreguil C, Troll M (2007a) Forest cover changes in the northern Carpathians in the 20th century: a slow transition. J Land Use Sci 2:127-146. doi:10.1080/17474230701218244

Kozak J, Estreguil C, Vogt P (2007b) Forest cover and pattern changes in the Carpathians over the last decades. Eur J For Res 126:77-90. doi:10.1007/s10342-006-0160-4

Kriegler E, O'Neill BC, Hallegatte S et al (2012) The need for and use of socio-economic scenarios for climate change analysis: a new approach based on shared socio-economic pathways. Glob Environ Change 22:807-822. doi:10.1016/j.gloenvcha.2012.05. 005

Kuemmerle T, Müller D, Griffiths P, Rusu M (2008) Land use change in Southern Romania after the collapse of socialism. Reg Environ Change 9:1-12. doi:10.1007/s10113-008-0050-Z

Lerman Z, Csaki C, Feder G (2004) Evolving farm structures and land use patterns in former socialist countries. Q J Int Agric 43:309-336

MacDonald D, Crabtree J, Wiesinger G et al (2000) Agricultural abandonment in mountain areas of Europe: environmental consequences and policy response. J Environ Manag 59:47-69. doi:10.1006/jema.1999.0335

MADR (2012) Programul Naţional de Dezvoltare Rurală 2007-2013. National Rural Development Program. Ministry of Agriculture and Rural Development of Romania

Maeda EE, Clark BJF, Pellikka P, Siljander M (2010) Modelling agricultural expansion in Kenya's Eastern Arc Mountains biodiversity hotspot. Agric Syst 103:609-620. doi:10.1016/j. agsy.2010.07.004

Maeda EE, de Almeida CM, de Carvalho Ximenes A et al (2011) Dynamic modeling of forest conversion: simulation of past and future scenarios of rural activities expansion in the fringes of the Xingu National Park, Brazilian Amazon. Int J Appl Earth Obs Geoinf 13:435-446. doi:10.1016/j.jag.2010.09.008

Malek Ž, Scolobig A, Schröter D (2014) Understanding land cover changes in the Italian Alps and Romanian Carpathians combining remote sensing and stakeholder interviews. Land 3:52-73. doi:10.3390/land3010052

Mas J-F, Soares Filho B, Pontius RG et al (2013) A suite of tools for ROC analysis of spatial models. ISPRS Int J Geo-Inf 2:869-887. doi:10.3390/ijgi2030869

Mather A (2001) The transition from deforestation to reforestation in Europe. In: Angelsen A, Kaimowitz D (eds) Agricultural technologies and tropical deforestation. CABI, Wallingford, p 422

Mathijs E, Swinnen JFM (1998) The economics of agricultural decollectivization in East Central Europe and the former Soviet Union. Econ Dev Cult Change 47:1-26. doi:10.1086/ 452384

Micu M, Bălteanu D (2013) A deep-seated landslide dam in the Siriu Reservoir (Curvature Carpathians, Romania). Landslides 10:323-329. doi:10.1007/s10346-013-0382-8

Millenium Ecosystem Assessment (2005) Ecosystems and human well-being: synthesis. Island Press, Washington, DC

Mitsova D, Shuster W, Wang X (2011) A cellular automata model of land cover change to integrate urban growth with open space conservation. Landsc Urban Plan 99:141-153. doi:10.1016/j. landurbplan.2010.10.001

Muică N, Turnock D (2008) A toponomical approach to the agrarian history of the Pătârlagele Depression (Buzău Subcarpathians, România). Hum Geogr 2:928-949

Müller D, Kuemmerle T, Rusu M, Griffiths P (2009) Lost in transition: determinants of post-socialist cropland abandonment in Romania. J Land Use Sci 4:109-129. doi:10.1080/ 17474230802645881

Munteanu C, Kuemmerle T, Boltiziar M et al (2014) Forest and agricultural land change in the Carpathian region-a meta- analysis of long-term patterns and drivers of change. Land Use Policy 38:685-697. doi:10.1016/j.landusepol.2014.01.012

Navarro LM, Pereira HM (2012) Rewilding abandoned landscapes in Europe. Ecosystems 15:900-912. doi:10.1007/s10021-012-9558-7

Olofsson P, Foody GM, Stehman SV, Woodcock CE (2013) Making better use of accuracy data in land change studies: estimating accuracy and area and quantifying uncertainty using stratified estimation. Remote Sens Environ 129:122-131. doi:10.1016/j. rse.2012.10.031

Olsson EGA, Austrheim G, Grenne SN (2000) Landscape change patterns in mountains, land use and environmental diversity, Mid-Norway 1960-1993. Landsc Ecol 15:155-170. doi:10.1023/ A: 1008173628016

Papathoma-Köhle M, Glade T (2013) The role of vegetation cover change for landslide hazard and risk. In: Renaud FG, SudmeierRieux K, Estrella M (eds) The role of ecosystems in disaster risk reduction. UNU-Press, Tokyo, pp 293-320

Parlamentul României (1996) Law No. 26/1996. The Romanian Forest Code. Monitorul Oficial. Official Journal of Romania, Bucharest

Petschko H, Brenning A, Bell R et al (2014) Assessing the quality of landslide susceptibility maps-case study lower Austria. Nat Hazards Earth Syst Sci 14:95-118. doi:10.5194/nhess-14-952014

Phillips C, Marden M (2005) Reforestation schemes to manage regional landslide risk. In: Glade T, Anderson M, Crozier MJ (eds) Landslide hazard risk. Wiley, New York, pp 517-547

Pontius RG Jr, Parmentier B (2014) Recommendations for using the relative operating characteristic (ROC). Landsc Ecol 29:367-382. doi:10.1007/s10980-013-9984-8

Pontius RG Jr, Schneider LC (2001) Land-cover change model validation by an ROC method for the Ipswich watershed, Massachusetts, USA. Agric Ecosyst Environ 85:239-248. doi:10.1016/S0167-8809(01)00187-6

Pontius RG Jr, Boersma W, Castella J-C et al (2007a) Comparing the input, output, and validation maps for several models of land change. Ann Reg Sci 42:11-37. doi:10.1007/s00168-007-0138-2

Pontius RG Jr, Walker R, Yao-Kumah R et al (2007b) Accuracy assessment for a simulation model of Amazonian deforestation. Ann Assoc Am Geogr 97:677-695. doi:10.1111/j.1467-8306. 2007.00577.x

Pontius RG Jr, Peethambaram S, Castella J-C (2011) Comparison of three maps at multiple resolutions: a case study of land change simulation in Cho Don district, Vietnam. Ann Assoc Am Geogr 101:45-62. doi:10.1080/00045608.2010.517742

Promper C, Puissant A, Malet J-P, Glade T (2014) Analysis of land cover changes in the past and the future as contribution to landslide risk scenarios. Appl Geogr 53:11-19. doi:10.1016/j. apgeog.2014.05.020

Quantum GIS Development Team (2013) Quantum GIS Geographic Information System. Open Source Geospatial Foundation Project

Reichenbach P, Busca C, Mondini AC, Rossi M (2014) The Influence of land use change on landslide susceptibility zonation: the Briga catchment test site (Messina, Italy). Environ Manag. doi:10. 1007/s00267-014-0357-0

Reichenbach P, Busca C, Mondini AC, Rossi M (2015) Land use change scenarios and landslide susceptibility zonation: the Briga Catchment Test Area (Messina, Italy). In: Lollino G, Manconi A, Clague $\mathbf{J}$ et al (eds) Engineering Geology for Society and Territory, vol 1. Springer International Publishing, pp 557-561

Rounsevell M, Reginster I, Araújo MB et al (2006) A coherent set of future land use change scenarios for Europe. Agric Ecosyst Environ 114:57-68. doi:10.1016/j.agee.2005.11.027

Schelhaas MJ, van Brusselen J, Pussinen A, et al. (2006) Outlook for the Development of European Forest Resources, a study prepared by the European Forest Sector Outlook Study (EFSOS). 
United Nations Economic Commission for Europe (UNECE), Geneva

Schmidt KM, Roering JJ, Stock JD et al (2001) The variability of root cohesion as an influence on shallow landslide susceptibility in the Oregon Coast Range. Can Geotech J 38:995-1024. doi:10. 1139/t01-031

Shearer AW (2005) Approaching scenario-based studies: three perceptions about the future and considerations for landscape planning. Environ Plan B Plan Des 32:67-87. doi:10.1068/b3116

Soares-Filho BS, Cerqueira GC, Pennachin CL (2002) Dinamica-a stochastic cellular automata model designed to simulate the landscape dynamics in an Amazonian colonization frontier. Ecol Model 154:217-235. doi:10.1016/S0304-3800(02)00059-5

Soares-Filho BS, Nepstad DC, Curran LM et al (2006) Modelling conservation in the Amazon basin. Nature 440:520-523. doi:10. 1038/nature04389

Taff GN, Müller D, Kuemmerle T et al (2009) Reforestation in Central and Eastern Europe after the breakdown of socialism. In: Nagendra H, Southworth J (eds) Reforesting landscapes. Springer, Dordrecht, pp 121-147

Tasser E, Mader M, Tappeiner U (2003) Effects of land use in alpine grasslands on the probability of landslides. Basic Appl Ecol 4:271-280. doi:10.1078/1439-1791-00153

Thapa RB, Shimada M, Watanabe M et al (2013) The tropical forest in south east Asia: monitoring and scenario modeling using synthetic aperture radar data. Appl Geogr 41:168-178. doi:10. 1016/j.apgeog.2013.04.009

Van Maanen E, Predoiu G, Klaver R et al (2006) Safeguarding the Romanian Carpathian ecological network. A vision for large carnivores and biodiversity in Eastern Europe. Icas Wildlife Unit, Brasov
Van Vliet J, Bregt AK, Hagen-Zanker A (2011) Revisiting Kappa to account for change in the accuracy assessment of land-use change models. Ecol Model 222:1367-1375. doi:10.1016/j. ecolmodel.2011.01.017

Veldkamp A, Lambin E (2001) Predicting land-use change. Agric Ecosyst Environ 85:1-6. doi:10.1016/S0167-8809(01)00199-2

Verburg PH, Schot PP, Dijst MJ, Veldkamp A (2004) Land use change modelling: current practice and research priorities. GeoJournal 61:309-324. doi:10.1007/s10708-004-4946-y

Visser H, de Nijs T (2006) The map comparison kit. Environ Model Softw 21:346-358. doi:10.1016/j.envsoft.2004.11.013

Wijesekara GN, Farjad B, Gupta A et al (2014) A comprehensive land-use/hydrological modeling system for scenario simulations in the Elbow River Watershed, Alberta, Canada. Environ Manag 53:357-381. doi:10.1007/s00267-013-0220-8

Wollenberg E, Edmunds D, Buck L (2000) Using scenarios to make decisions about the future: anticipatory learning for the adaptive co-management of community forests. Landsc Urban Plan 47:65-77. doi:10.1016/S0169-2046(99)00071-7

Yanai AM, Fearnside PM, de Graça PMLA, Nogueira EM (2012) Avoided deforestation in Brazilian Amazonia: simulating the effect of the Juma Sustainable Development Reserve. For Ecol Manag 282:78-91. doi:10.1016/j.foreco.2012.06.029

Zimmermann P, Tasser E, Leitinger G, Tappeiner U (2010) Effects of land-use and land-cover pattern on landscape-scale biodiversity in the European Alps. Agric Ecosyst Environ 139:13-22. doi:10. 1016/j.agee.2010.06.010

Zumpano V, Hussin HY, Reichenbach P et al (2014) A landslide susceptibility analysis for Buzau County, Romania. Romanian J Geogr 58:9-16 